\title{
Psychological Resources of the Modification in Self-Fulfillment of Personality
}

\section{Психологічні ресурси перетворень у самоздійсненні особистості}

\author{
Olena Shtepa \\ Ph.D. in Psychology, Assistant Professor, Ivan Franko National \\ University of Lviv, Lviv (Ukraine) \\ ORCID ID: https://orcid.org/0000-0002-5396-3279 \\ Researcher ID: http://www.researcherid.com/rid/S-9557-2018 \\ E-mail: Olena.Shtepa@lnu.edu.ua

\section{Олена Штепа} \\ Кандидат психологічних наук, доцент, Львівський націо- \\ нальний університет імені Івана Франка, м. Львів (Україна)
}

\section{ABSTRACT}

The aim of the article is an empirical definition of the psychological resources of modification in the self-fulfillment of the person.

The empirical study used methods of psychological questioning, as well as such methods of mathematical and statistical data analysis, in particular, regression, correlation, classification, discriminant, and multifactor analysis. The empirical study was implemented according to Nelson's model, which made it possible to characterize the required psychological resources by discriminating against them.

Research results. It was found that the reflected psychological resources in the configurations of self-fulfillment - existential, personal, and professional self-fulfillment - are: creativity, work on yourself, the ability to update their own

Address for correspondence, e-mail: kpnu_lab_ps@ukr.net Copyright: (c) Shtepa Olena

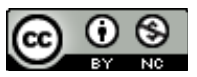

(C) Shtepa Olena 
resources, coherence, charity, meaningful life, expression of emotions. Interpretive resources "creativity" and "ability to update own resources" are predictors of all three configurations of self-realization. Psychological resources that moderate the relationship of existential motivation as a manifestation of the inner world of man and life tasks are identified as creativity, self-work, coherence, charity, expression of emotions. Psychological resources that are factors of self-realization, self-actualization, self-fulfillment of the person are creativity, the ability to update their own resources, coherence. Coherence is a factor for all three configurations of self-realization.

Conclusions. The sequence of the resourcefulness of changes in self-fulfillment is as follows: first, due to the resource of work on oneself, self-actualization is carried out, the effect of which is existential self-fulfillment as a sense of real and authorial life lived by the person; further, the ability to update their own resources leads to the transformation of forms in personal and professional self-fulfillment; at the end of the change, the resource of creativity affects the possibility of self-fulfillment of the person. The whole process of reflected changes is patronized by coherence, as a factor in the significance of a life lived by the person, as well as its optimal and healthy functioning.

Key words: psychological resources, self-actualization, self-realization, self-fulfillment, personal changes.

\section{Introduction}

Self-fulfillment is characterized as the disclosure of a person's own essence, up to a certain time of potential opportunities, which is realized in his self-transcendence, the transition to his own different being as a personality (Гуменюк, 2014). Self-fulfillment is one of the current problems of European personality psychology, as evidenced by studies on the personal characteristics of people with different levels of self-fulfillment as one of the types of human well-being, as the realization of "good life» (Shutenko, 2015; Krems et all., 2017; Clark, 2018). In particular, researchers found that individuals with a higher level of self-fulfillment are characterized by selfesteem, self-management skills, a sense of saturation of life; individuals with a low level of self-fulfillment are characterized by an unmet need for security, closeness to new expe(c) Shtepa Olena

DOI (article): https://doi.org/10.32626/2227-6246.2021-53.330-354 
DOI: https://doi.org/10.32626/2227-6246.2021-53

2021. випуск 53

riences, self-esteem difficulties, excessive internal contradictions (Shutenko, 2015: 331). It has been found that self-realization is one of the invariants of a person's sense of self-wellbeing, which differs from subjective, hedonistic, eudemonistic well-being functionally: the results achieved in the process of self-realization become the basis for further self-fulfillment (Krems et. al., 2017). It is characterized that self-fulfillment is possible with the predominance of self-understanding over perfectionism (Clark, 2018: 378).

The stereotypes concerning exaggerated self-importance, underdeveloped ability to self-knowledge, unformed mechanisms of self-development, and, as a result, the inability of a person to be subjects of self-development have been proved to be obstacles to self-realization by scientists (Maksymenko \& Serdiuk, 2016: 98). At the same time, it is in the existential paradigm that it is argued a person can accept uncertainty and open up to opportunities, learn to perceive difficulties and mistakes as opportunities for self-development, in the course of rethinking, which leads to personal change and is the effect of life (Леонтьев \& Миюзова, 2016: 59). Researchers have shown that the source of personal change is an existential experience (Гришина, 2013: 384), the changes themselves occur when at the level of the existing state of self-fulfillment a person does not find a solution to their own personal problems, which are mainly problems of self-understanding. Changes in the status of self-fulfillment are characterized as cardinal, radical, occurring abruptly, without prior accumulation of small changes, they are indeterminate by self-consciousness (Mobilis in mobili..., 2018: 87, 103, 121) and lead to qualitative changes observed as a qualitative difference of personality (Изменения, 2010).

At present, there are two views in the psychology of personality on the determinants of personal change: the statement about the possibility of resolving contradictions and increase (C) Shtepa Olena

DOI (article): https://doi.org/10.32626/2227-6246.2021-53.330-354 
creativity due to the impact on self-fulfillment primarily by the professional self-fulfillment (Byundyugova \& Kornienko, 2015), and judgments about self-change as a mechanism of self-development. The psychological resources that correlate the relationship between the individual's inner reality and his life tasks play a significant role in self-change (Низовских, 2014: 35, 367). Probably, professional self-fulfillment is given the priority in causing changes in human self-realization in life because they see in a person's desire to reach professional heights the inevitable disclosure of his own potential (Психологічні технології ефективного функціонування..., 2019: 274). At the same time, scientists note that potential opportunities are revealed in the process of personal self-fulfillment, resulting in socially significant effects and the formation of their own «space of life» (Кокун, 2013: 3). Internal coherence, which is manifested in openness, determination, and clarity in the correlation of personal values and ways of their implementation, characterizes the essence of existential self-fulfillment (Кривцова и др., 2009).

To solve the problem of such transformations in self-realization, scientific expediency obliges to take into account both views on the causes of changes in self-fulfillment and to analyze both configurations including professional and the role of psychological resources in the structure of self-fulfillment. At the same time, since we rely on the definition of personality as «a form of the human psyche, which is a unity capable to self-development, self-determination, conscious substantive activity, and self-regulation, and has its own unique inner world» (Максименко, 2016: 11), we are more inclined to believe that radical changes in self-fulfillment are due to the person's awareness of their own psychological resources, through which it moderates the relationship between their own inner world and life task. It is important to determine the psychological resources of different configurations of self-fulfillment -

(C) Shtepa Olena

DOI (article): https://doi.org/10.32626/2227-6246.2021-53.330-354 
DOI: https://doi.org/10.32626/2227-6246.2021-53

2021. випуск 53

existential, personal, professional - to characterize the possibilities of change in the self-fulfillment of the personality.

The aim of the study is an empirically determination of the psychological resources of transformation in the self-fulfillment of the personality.

\section{The aim of the article}

The task of the article was to identify the psychological resources contained in such configurations of self-fulfillment of the personality empirically as existential, personal, and professional self-fulfillment; empirically determine the psychological resources that established the relationship between the inner world of man and life tasks; empirically establish psychological resources that were factors of self-fulfillment, self-actualization, self-realization of the personality.

The empirical study is implemented according to Nelson's model, which makes it possible to characterize the desired discrimination in determining its indicators.

The following psychodiagnostic methods were used in the empirical study: O. Shtepa's psychological resourcefulness questionnaire, E. Riazantseva's test-questionnaire for diagnosing indicators of existential resources of personality, selfassessment questionnaire of "character forces», built by us on the basis of «Virtues and strengths of character» questionnaire (methods of Values in Action by K. Peterson and M. Seligman adapted by I. Burovikhina, D. Leontiev, E. Osin), the questionnaire of management of crisis states by M. Laad, the questionnaire of psychological well-being (method by K. Riff adapted by S. Karskanova), the method of determining (in)tolerance to the uncertainty of S. Badlaire (adaptation of H. Soldatova, L. Shaiherova), methods of assessing and predicting the psychological development of situations of interpersonal interaction of $\mathrm{O}$. Bondarenko, the questionnaire of reflection of D. Leontiev, E. Osin, the questionnaire of loss and acquisiC Shtepa Olena

DOI (article): https://doi.org/10.32626/2227-6246.2021-53.330-354 
DOI: https://doi.org/10.32626/2227-6246.2021-53

2021. випуск 53

tion of personal resources (developed by N. Vodopianova and M. Stein), A. Antonovski's coherence scale in the adaptation of E. Osin, the questionnaire of the reflection by D. Leontiev, E. Osin, questionnaire of existential fulfillment in the version of V. Shumskyi, E. Ukolova, E. Osin, Ya. Lupandin, the questionnaire of personality self-fulfillment of O. Shtepa, the questionnaire of professional self-fulfillment of O. Kokun, the questionnaire of developmental life tasks (the work of the staff of the laboratory of social psychology of personality of ISPP NAPS of Ukraine under the leadership of T. Tytarenko), the questionnaire of the effectiveness of self-realization of E. Selezniova, the questionnaire of self-actualization of personality in the adaptation of $\mathrm{H}$. Nikiforova.

In our opinion, the transformation in the self-fulfillment of the personality is characterized by the simultaneous manifestation of self-actualization, self-realization, and, in fact, self-fulfillment as the disclosure of potential opportunities. We consider he empirical descriptor of transformations in self-realization to be the presence at a statistically significant level of relationships between indicators of self-realization, self-actualization, and self-fulfillment of the personality.

We assume that the psychological resources of transformations in self-fulfillment correspond to each of the following characteristics:

- discriminated by configurations of self-fulfillment (personal, existential, professional self-fulfillment);

- they are predictors of personal, existential, professional self-fulfillment;

- discriminated against by systemic reflection;

- associated with certain existential motives and life tasks;

- they are related to self-realization, self-actualization, self-fulfillment and are their factors.

(C) Shtepa Olena

DOI (article): https://doi.org/10.32626/2227-6246.2021-53.330-354 
DOI: https://doi.org/10.32626/2227-6246.2021-53

2021. випуск 53

Based on the definition of personality as a phenomenon of the human self and the inextricably linked motivational orientation (Капустин, 2017: 70), we have identified existential motives as an empirical descriptors of the inner world of man. Assuming a variety of life tasks of the individual during his life, we have identified the empirical descriptor of the person's life tasks to be the operational analogs of life tasks.

The study involved 105 people aged 32-50 years (average $=40.4$ ) (including 53 women, 42 men) (lawyers, doctors, teachers, lecturers, entrepreneurs). All respondents have work experience (from 10 to 28 years), $80 \%$ of respondents are married, $75 \%$ are raising a child, 5\% have experience of divorce, $2 \%$ - the experience of being in a second marriage, $77 \%$ - the experience of losing a loved one, $7 \%$ - the experience of losing a job, 31\% have received a second education and changed jobs, $30 \%$ have experience of (failure)success in business, 36\% have lived in the city for the last 12 years, 8\% have experience of changing country of residence, $12 \%$ - the experience of receiving psychological assistance, $52 \%$ are interested in publications on psychological topics. These data on the subjects to some extent present their life experience and, in our opinion, allow us to form an idea of the saturation of existential, personal, professional self-realization, as well as a more realistic interpretation of the psychological resources of transformations of their self-fulfillment.

\section{Results and discussions}

To determine the psychological resources that are included in the configurations of self-fulfillment (existential, personal, professional self-fulfillment), discriminant analysis was used (Tables 1, 2, 3). The discriminant analysis included a total of 66 psychological resources, including coherence, personal resources, existential resources, "character forces», motivational resources for psychological well-being, tolerance for uncer(C) Shtepa Olena

DOI (article): https://doi.org/10.32626/2227-6246.2021-53.330-354 
DOI: https://doi.org/10.32626/2227-6246.2021-53

2021. випуск 53

tainty, interpretive psychological resources, and relationship resources.

It was found that among the psychological resources included in discriminant analysis, existential self-fulfillment is expressed by the average (Wilks' Lambda 0.49) 6 resources: personal resources, coherence as a resource with a filtering function, existential resource of charity, personal growth (motivational resource of psychological well-being), creativity and the ability to update resources as interpretive psychological resources.

At a low Wilks' Lambda 0.23 personal self-fulfillment outlines 9 psychological resources (Table 2).

The resources of expression of personal self-fulfillment revealed the following: interpretive psychological resources the ability to update their own resources, creativity, work on themselves; existential resources - charity and acceptance, motivational resources of psychological well-being - positive relationships with others and goals in life, courage «strength of character».

According to the Wilks' Lambda indicator, the most pronounced is the discriminatory model of professional self-fulfillment resources (Wilks' Lambda 0.75), which contains 5 resources (Table 3).

Psychological resources, contained in professional self-fulfillment, include: expression of emotions as a resource of psychological survival, self-acceptance as a motivational resource of psychological well-being, meaningful life «strength of character", creativity and ability to update their own resources as interpretive psychological resources.

To find out which of the discriminated psychological resources are predictors of self-fulfillment configurations, a classification analysis was used, the results of which are presented in Table 4.

(C) Shtepa Olena

DOI (article): https://doi.org/10.32626/2227-6246.2021-53.330-354 
DOI: https://doi.org/10.32626/2227-6246.2021-53

2021. випуск 53

$\frac{\pi}{0}$

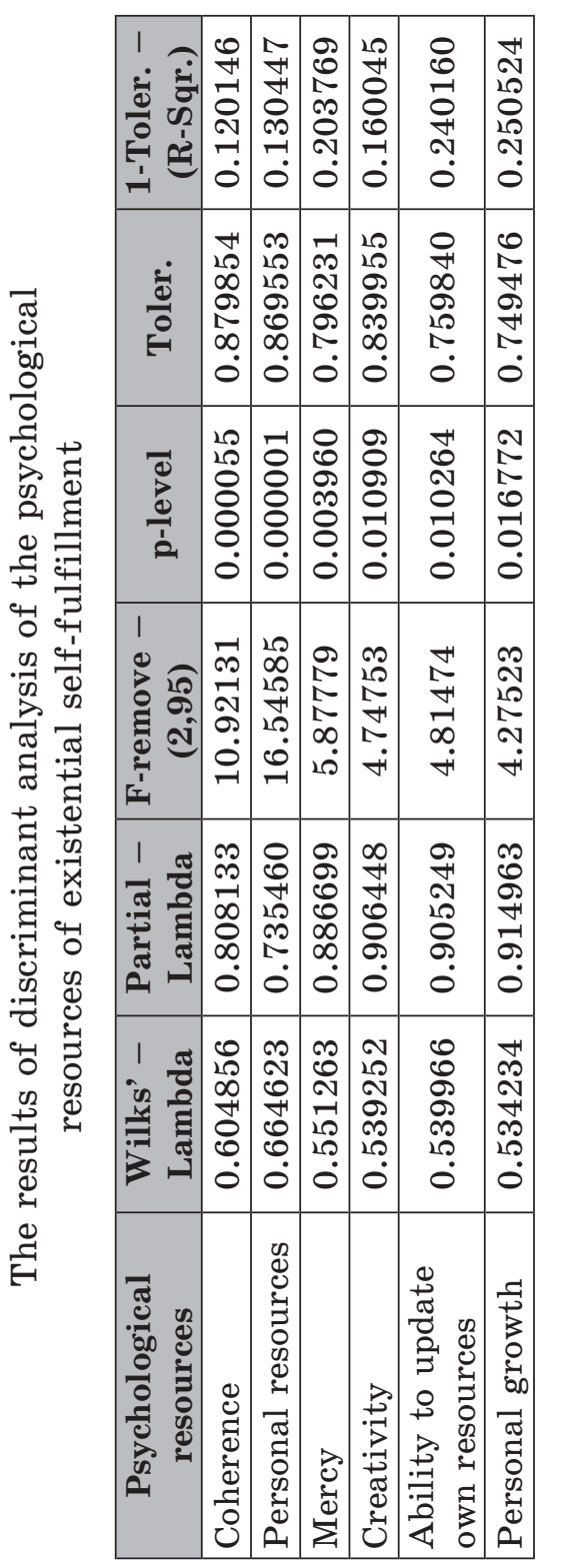

0
0
0
0
$\sigma$

ల్

है,

号

范艺

Q2

तो

ते छ

శ్ర శ్

르유.

舟

凋

4

告

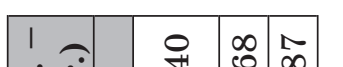

\begin{tabular}{|c|c|c|c|c|}
\hline$\underset{\sim}{\sim}$ & & 욤 & 官 & m \\
\hline$\frac{\dot{0}}{\frac{0}{0}}$ & 0 & 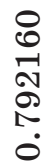 & 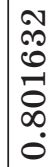 & $\begin{array}{l}\infty \\
-1 \\
0 \\
0 \\
\infty \\
0 \\
0\end{array}$ \\
\hline
\end{tabular}

\begin{tabular}{|c|c|c|c|c|}
\hline$\frac{1}{2}$ & 20 & $\begin{array}{l}8 \\
8 \\
8 \\
8 \\
8\end{array}$ & 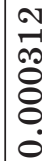 & $\begin{array}{l}\stackrel{+}{\infty} \\
0 \\
0 \\
0 \\
0 \\
0 \\
0\end{array}$ \\
\hline
\end{tabular}

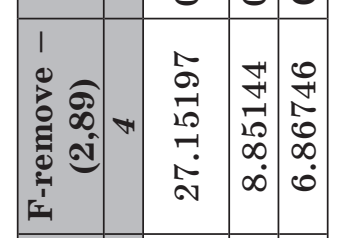

\begin{tabular}{|c|c|c|c|c|}
\hline 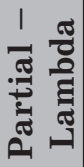 & ต & \begin{tabular}{l}
$\infty$ \\
10 \\
0 \\
\\
\multirow{1}{0}{} \\
0 \\
0
\end{tabular} & 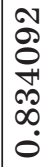 & $\begin{array}{l}1 \\
0 \\
0 \\
0 \\
0 \\
\infty \\
0\end{array}$ \\
\hline 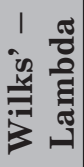 & N & 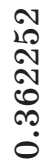 & 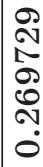 & $\begin{array}{l}0 \\
0 \\
0 \\
0 \\
10 \\
\text { ஸे } \\
0\end{array}$ \\
\hline
\end{tabular}

(C) Shtepa Olena

DOI (article): https://doi.org/10.32626/2227-6246.2021-53.330-354 


\begin{tabular}{|c|c|c|c|c|c|c|}
\hline N & $\begin{array}{l}0 \\
\text { Oे } \\
\text { Oे } \\
\text { ஸे } \\
0\end{array}$ & $\begin{array}{l}\stackrel{0}{+1} \\
\text { m. } \\
\stackrel{-1}{0} \\
\dot{+}+ \\
\dot{0}\end{array}$ & $\begin{array}{l}8 \\
\infty \\
\infty \\
+1 \\
+1 \\
\dot{10} \\
0\end{array}$ & 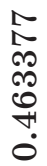 & $\begin{array}{l}\stackrel{+}{N} \\
\stackrel{+}{+} \\
\stackrel{0}{0} \\
\stackrel{-}{0}\end{array}$ & $\begin{array}{l}\mathbb{J}^{\prime} \\
\text { ஸे } \\
\stackrel{+}{+} \\
\dot{0}\end{array}$ \\
\hline 0 & 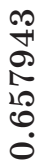 & $\begin{array}{l}0 \\
0 \\
0 \\
\infty \\
\text { ஸे } \\
10 \\
0\end{array}$ & $\begin{array}{l}\stackrel{0}{1} \\
\underset{1}{\infty} \\
+1 \\
0 \\
0 \\
0\end{array}$ & 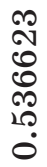 & 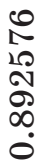 & $\begin{array}{l}0 \\
0 \\
0 \\
0 \\
\infty \\
\infty \\
0\end{array}$ \\
\hline مג & $\begin{array}{l}0 \\
\text { +' } \\
8 \\
8 \\
8 \\
0\end{array}$ & $\begin{array}{l}\text { ㄱ. } \\
\text { ᄋ } \\
8 \\
8 \\
0 \\
0\end{array}$ & $\begin{array}{l}\infty \\
8 \\
ᄋ \\
ᄋ\end{array}$ & $\begin{array}{l}\infty \\
0 \\
0 \\
0 \\
8 \\
0 \\
0\end{array}$ & $\begin{array}{l}\text { N } \\
\text { ㄱ. } \\
\text { i̊ } \\
8 \\
0 \\
0\end{array}$ & 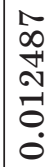 \\
\hline$\nabla$ & 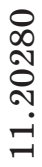 & 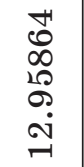 & 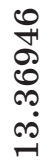 & $\begin{array}{l}10 \\
10 \\
10 \\
0 \\
10 \\
0\end{array}$ & $\begin{array}{l}8 \\
0 \\
\infty \\
10 \\
\text { i } \\
10\end{array}$ & 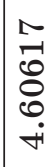 \\
\hline ח & $\begin{array}{l}\infty \\
\infty \\
\infty \\
\infty \\
\infty \\
0 \\
\dot{0}\end{array}$ & $\begin{array}{l}\stackrel{0}{N} \\
\frac{+}{N} \\
\stackrel{N}{0} \\
\dot{0}\end{array}$ & 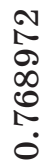 & 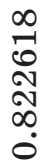 & $\begin{array}{l}\infty \\
\infty \\
\infty \\
\infty \\
\infty \\
\infty \\
\infty\end{array}$ & 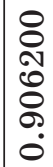 \\
\hline v & 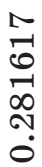 & 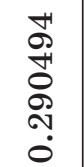 & 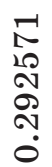 & 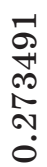 & 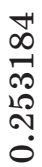 & 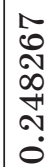 \\
\hline- & 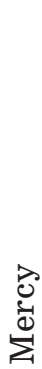 & 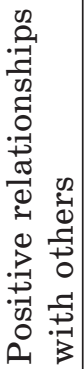 & 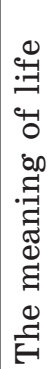 & 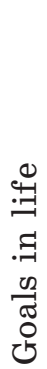 & 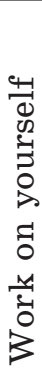 & 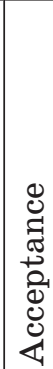 \\
\hline
\end{tabular}

$n$
0
0
0
0

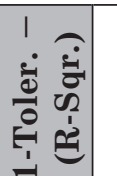

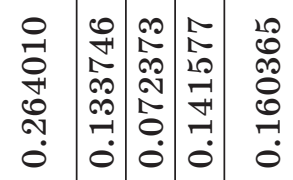

ల్ర

So

응

\begin{tabular}{|c|c|c|c|c|}
\hline 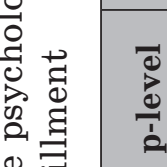 & 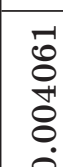 & \begin{tabular}{l}
0 \\
$\sigma$ \\
$\sigma$ \\
\hdashline \\
0
\end{tabular} & 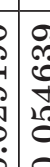 & 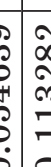 \\
\hline
\end{tabular}

过

廿⿻一𠃋十

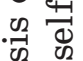

त्]

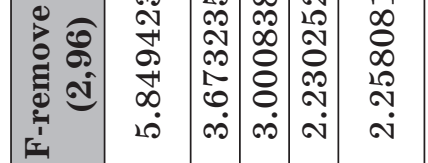

忌

. फ

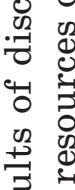

\begin{tabular}{|c|c|c|c|c|}
\hline 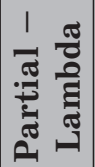 & $\begin{array}{l}+ \\
\infty \\
\Gamma \\
\infty \\
\infty \\
\infty \\
0\end{array}$ & 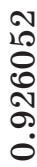 & $\begin{array}{l}0 \\
10 \\
1 \\
\infty \\
\infty \\
0 \\
0\end{array}$ & $\begin{array}{l}\infty \\
1 \\
1 \\
\kappa \\
1 \\
0 \\
0 \\
0\end{array}$ \\
\hline
\end{tabular}

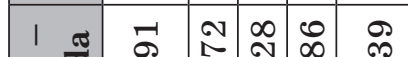

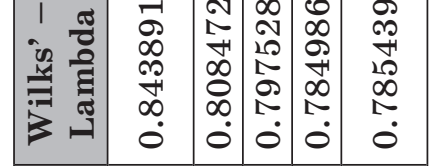

巳

를

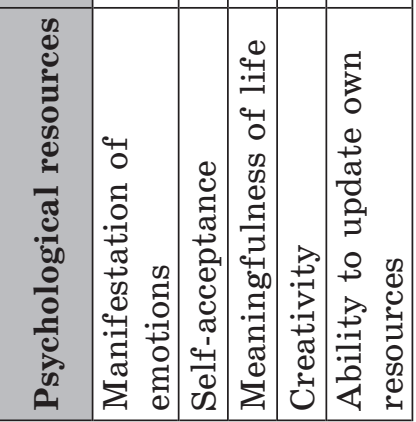

(C) Shtepa Olena

DOI (article): https://doi.org/10.32626/2227-6246.2021-53.330-354 
Psychological resources-predictors of self-fulfillment configurations (ranging $0-\min , 100-\max$ )

\begin{tabular}{|c|c|c|c|c|c|}
\hline \multicolumn{2}{|c|}{$\begin{array}{c}\text { Psychological } \\
\text { resources-predictors } \\
\text { of existential } \\
\text { self-fulfillment } \\
\end{array}$} & \multicolumn{2}{|c|}{$\begin{array}{c}\text { Psychological } \\
\text { resources-predictors } \\
\text { of personality } \\
\text { self-fulfillment }\end{array}$} & \multicolumn{2}{|c|}{$\begin{array}{c}\text { Psychological } \\
\text { resources-predictors } \\
\text { of professional } \\
\text { self-fulfillment }\end{array}$} \\
\hline Creativity & 85 & Creativity & 69 & Creativity & 70 \\
\hline $\begin{array}{l}\text { Ability to update } \\
\text { own resources }\end{array}$ & 86 & \begin{tabular}{|l|} 
Ability to \\
update their own \\
psychological \\
resources
\end{tabular} & 56 & $\begin{array}{l}\text { Ability to } \\
\text { update their own } \\
\text { psychological } \\
\text { resources }\end{array}$ & 83 \\
\hline $\begin{array}{l}\text { Personal } \\
\text { resourcefulness }\end{array}$ & 78 & Work on yourself & 46 & $\begin{array}{l}\text { Manifestation of } \\
\text { emotions }\end{array}$ & 67 \\
\hline Personal growth & 19 & \begin{tabular}{|l} 
Positive \\
relationships \\
with others
\end{tabular} & 100 & Self-acceptance & 100 \\
\hline Coherence & 100 & $\begin{array}{l}\text { Meaningfulness } \\
\text { of life }\end{array}$ & 78 & $\begin{array}{l}\text { Meaningfulness } \\
\text { of life }\end{array}$ & 73 \\
\hline Mercy & 80 & Mercy & 73 & & \\
\hline & & Acceptance & 69 & & \\
\hline & & Courage & 66 & & \\
\hline & & Goals in life & 90 & & \\
\hline
\end{tabular}

Among psychological resources-predictors of configurations of self-fulfillment, it is expedient to pay attention that creativity and ability to update own psychological resources are predictors with a high rank $(\mathrm{P} 1=69-85, \mathrm{P} 1=56-86)$ for all three configurations of self-fulfillment. The existential resource of charity is common for existential and personal self-fulfillment and it is a predictor with a high rank for each of them $\left(\mathrm{PM}_{\mathrm{e}}=80, \mathrm{PM}_{\mathrm{o}}=73\right)$; «Strength of character» meaningfulness of life is a common resource for personal and professional self-fulfillment and is a predictor with a high rank (C) Shtepa Olena

DOI (article): https://doi.org/10.32626/2227-6246.2021-53.330-354 
DOI: https://doi.org/10.32626/2227-6246.2021-53

2021. випуск 53

for each of them $\left(\mathrm{P}_{\mathrm{o}_{\mathrm{o}}}=78, \mathrm{P}_{\mathrm{m}}=73\right)$. The most important predictors (rank 100) in the configurations of self-fulfillment are different, in particular, for existential self-realization it is a filtering resource of coherence, and for personal and professional self-fulfillment motivational resources of positive relationships with others and self-acceptance.

We decided to find out which of the discriminated psychological resources are conscious, i.e. those that are provided by systemic reflection. To implement this task, a discriminant analysis was used, the results of which are presented in the Table 5.

Among the psychological resources contained in discriminatory models of existential, personal, professional self-fulfillment, only 7 are included in the locus of systemic reflection. Therefore, in the further analysis of the factors of self-fulfillment, only reflected resources were included, as such, which enable changes, but not modification in self-fulfillment.

In order to establish the factors of self-realization, selfactualization among the reflected psychological resources, the regression analysis was made.

According to the results of regression analysis, we can conclude that in addition to the differences, there are common factors of configurations of self-fulfillment. In particular, the interpretive resource of creativity is a factor for existential and professional self-fulfillment; coherence is a factor for all three configurations of self-fulfillment.

To determine the relationship between reflected resources and self-fulfillment, correlation analysis was used (Table 9), the results of which showed that the isolated psychological resources were more related to the overall rate of self-fulfillment $(\mathrm{r}=0.41-0.53 ; \mathrm{p}<0.01)$. It should be noted that the existential resource of charity at a statistically significant level $(p<0.01)$ is associated only with self-fulfillment.

(C) Shtepa Olena

DOI (article): https://doi.org/10.32626/2227-6246.2021-53.330-354 
DOI: https://doi.org/10.32626/2227-6246.2021-53

2021. виПУСК 53

$\frac{0}{0}$

엉

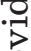

?

(2)

ల్ల

告

on

$\stackrel{0}{\circ}$

ฮู่

क्ष

ชี

एँ

है

हैं

थ2

궁

ฮ્త

ส

芑

苍 बि

4ै

岌

\begin{tabular}{|c|c|c|c|c|c|c|c|}
\hline 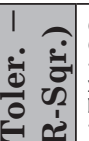 & $\begin{array}{l}\infty \\
N \\
N \\
\Sigma \\
N\end{array}$ & $\left|\begin{array}{c|}10 \\
0 \\
0 \\
10 \\
0 \\
7^{\prime}\end{array}\right|$ & $\begin{array}{l}\Omega \\
\stackrel{1}{二} \\
\\
\infty \\
\infty\end{array}$ & 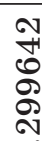 & $\begin{array}{l}m \\
\text { m } \\
\text { m }\end{array}$ & $\begin{array}{l}1 \\
0 \\
10\end{array}$ & 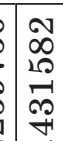 \\
\hline
\end{tabular}

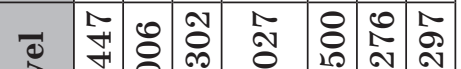

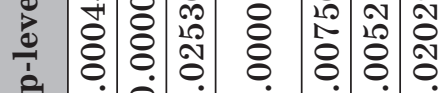

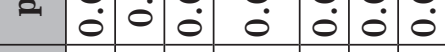

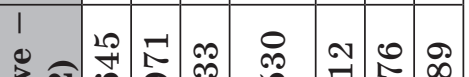

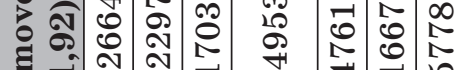

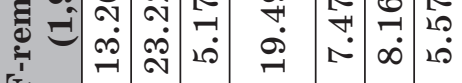

盾

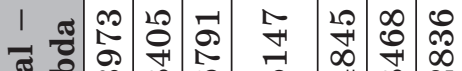

అ

జ

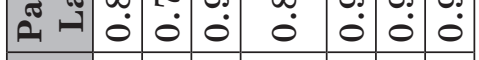

\begin{tabular}{|c|c|c|c|c|c|c|c|}
\hline 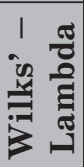 & 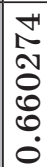 & 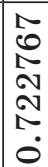 & 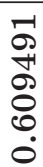 & 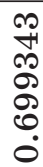 & 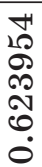 & $\begin{array}{l}0 \\
\infty \\
N \\
\infty \\
N \\
0 \\
0 \\
0\end{array}$ & \begin{tabular}{l}
$\infty$ \\
\multirow{+}{*}{} \\
0 \\
0 \\
0 \\
0
\end{tabular} \\
\hline
\end{tabular}

(1)

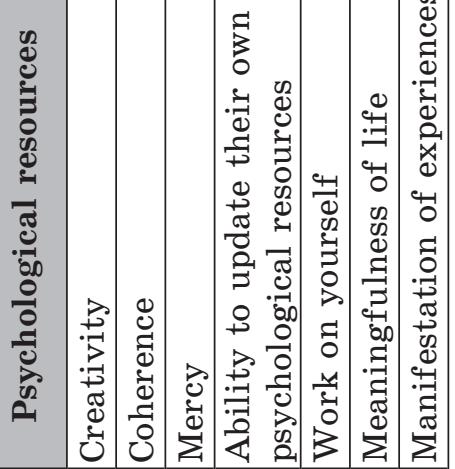

ขึ

-1
0
0
0
0
0

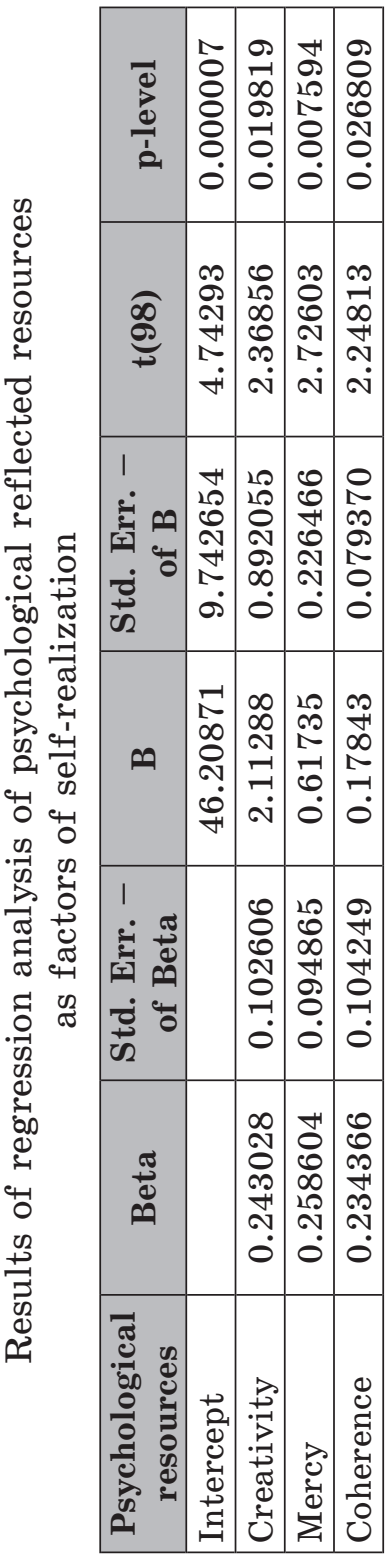

(C) Shtepa Olena

DOI (article): https://doi.org/10.32626/2227-6246.2021-53.330-354 
DOI: https://doi.org/10.32626/2227-6246.2021-53

2021. ВИПУСК 53

0
0
0
0
0

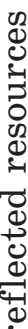

궁 . 80.

긍

공

仓

थै,

世

.

थ

ते

สี ซ్ర

대

ज्ञ

e

80

फ

$\stackrel{\square}{\leftrightarrows}$

尝

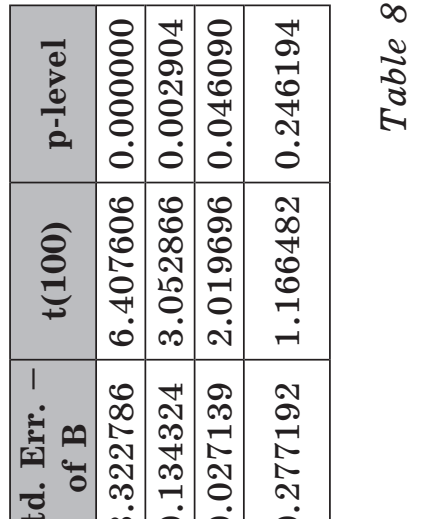

U

ल $\dot{0} 0 \dot{0}$

듬드 붕

$\oplus$

공

가 $0 \dot{0} 0 \dot{0}$

\begin{tabular}{|c|c|c|c|c|}
\hline 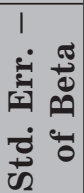 & & $\begin{array}{l}0 \\
0 \\
2 \\
\infty \\
0 \\
0 \\
\dot{0}\end{array}$ & 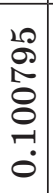 & 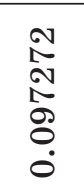 \\
\hline 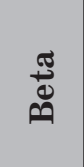 & & 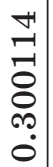 & $\begin{array}{l}0 \\
N \\
10 \\
m \\
0 \\
0 \\
0\end{array}$ & 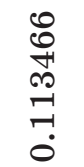 \\
\hline 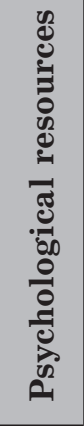 & 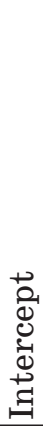 & 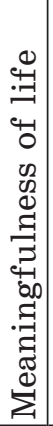 & 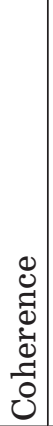 & 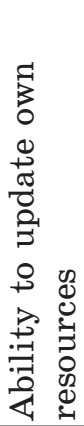 \\
\hline
\end{tabular}

थ

ส

造

पै थ

.2 0

Dे

ฮี

हี थै

$\cdot \frac{1}{0}$

ข2

5

$\overbrace{0}^{\circ}$

4-

号

\begin{tabular}{|c|c|c|c|c|c|c|}
\hline$\frac{0}{0}$ & 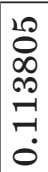 & $\begin{array}{l}\infty \\
10 \\
\infty \\
10 \\
0 \\
0 \\
0\end{array}$ & $\begin{array}{l}\infty \\
\infty \\
\infty \\
\infty \\
0 \\
0 \\
0\end{array}$ & $\begin{array}{l}\text { त } \\
\text { mo } \\
0 \\
0 \\
0\end{array}$ & 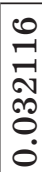 & 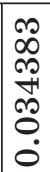 \\
\hline$\underbrace{\infty}_{t}$ & $\begin{array}{l}\infty \\
0 \\
10 \\
10 \\
0 \\
10 \\
-1\end{array}$ & $\begin{array}{l}\infty \\
N \\
1 \\
\kappa \\
\infty \\
\infty \\
0\end{array}$ & $\begin{array}{l}0 \\
\infty \\
+1 \\
0 \\
0 \\
0 \\
0\end{array}$ & 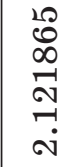 & 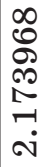 & $\begin{array}{l}9 \\
0 \\
20 \\
10 \\
71 \\
7 \\
\text { ن }\end{array}$ \\
\hline 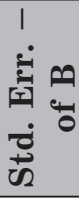 & 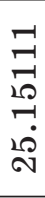 & $\begin{array}{l}\stackrel{N}{\sim} \\
\stackrel{\Omega}{\Omega} \\
\stackrel{0}{0} \\
\dot{0}\end{array}$ & $\begin{array}{l}10 \\
0 \\
\varrho \\
\stackrel{0}{0} \\
\stackrel{0}{0}\end{array}$ & $\begin{array}{l}\text { N } \\
\infty \\
\infty \\
\infty \\
\text { ஸे }\end{array}$ & 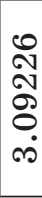 & 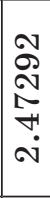 \\
\hline 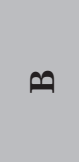 & 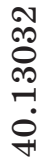 & 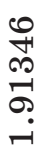 & $\begin{array}{l}\tilde{H}^{+} \\
10 \\
10 \\
10 \\
0\end{array}$ & $\begin{array}{l}\text { m } \\
\text { m} \\
\text { Jै } \\
\dot{+}\end{array}$ & $\begin{array}{l}\stackrel{N}{+} \\
\stackrel{N}{N} \\
\stackrel{N}{N} \\
\dot{0}\end{array}$ & $\begin{array}{l}0 \\
0 \\
10 \\
0 \\
0 \\
10 \\
10\end{array}$ \\
\hline 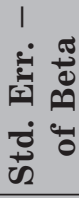 & & 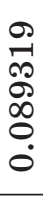 & 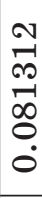 & $\begin{array}{l}N \\
\infty \\
N \\
\infty \\
\infty \\
0 \\
0\end{array}$ & \begin{tabular}{l}
$N$ \\
\multirow{H}{*}{} \\
\multirow{N}{N}{} \\
$\infty$ \\
0 \\
$\dot{0}$
\end{tabular} & $\begin{array}{l}1 \\
10 \\
\kappa \\
\kappa \\
\infty \\
0 \\
0 \\
0\end{array}$ \\
\hline 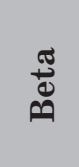 & & 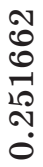 & $\begin{array}{l}0 \\
0 \\
0 \\
ㅁ \\
ㅁ \\
0\end{array}$ & $\begin{array}{l}20 \\
\infty \\
N \\
N \\
0 \\
0\end{array}$ & $\begin{array}{l}\overrightarrow{0} \\
\dot{1} \\
0 \\
\dot{1} \\
\dot{0}\end{array}$ & $\begin{array}{l}\infty \\
\infty \\
\infty \\
\infty \\
\infty \\
-1 \\
\dot{0}\end{array}$ \\
\hline 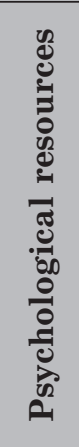 & 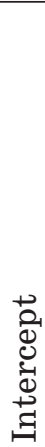 & 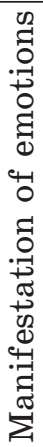 & 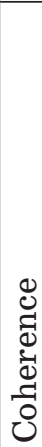 & 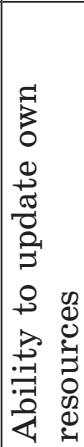 & 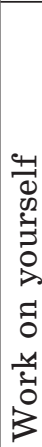 & 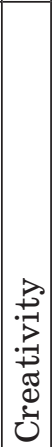 \\
\hline
\end{tabular}

(C) Shtepa Olena

DOI (article): https://doi.org/10.32626/2227-6246.2021-53.330-354 
The results of correlation analysis of reflected resources and indicators of transformation processes in the self-fulfillment of the personality

\begin{tabular}{|l|c|c|c|}
\hline \multirow{2}{*}{\begin{tabular}{c}
\multirow{2}{*}{$\begin{array}{c}\text { The reflected } \\
\text { psychological resources }\end{array}$} \\
\cline { 2 - 4 }
\end{tabular}} & \multicolumn{2}{|c|}{$\begin{array}{c}\text { The indicators of transformation } \\
\text { processes in the self-fulfillment } \\
\text { of the personality }\end{array}$} \\
\cline { 2 - 4 } & $\begin{array}{c}\text { self-reali- } \\
\text { zation }\end{array}$ & $\begin{array}{c}\text { self-actua- } \\
\text { lization }\end{array}$ & $\begin{array}{c}\text { self-ful- } \\
\text { fillment }\end{array}$ \\
\hline Creativity & $0.38 * *$ & $0.21 *$ & $0.46 * *$ \\
\hline Work on yourself & $0.20 *$ & $0.25 *$ & $0.41 * *$ \\
\hline $\begin{array}{l}\text { Ability to update own } \\
\text { resources }\end{array}$ & $0.24 *$ & $0.27 *$ & $0.45 * *$ \\
\hline Coherence & $0.26 *$ & $0.22 *$ & $0.45 * *$ \\
\hline Mercy & -0.12 & -0.03 & $0.25 *$ \\
\hline Meaningfulness of life & $0.21 *$ & $0.25 *$ & 0.11 \\
\hline Manifestation of emotions & $0.22 *$ & $0.27 *$ & $0.53 * *$ \\
\hline
\end{tabular}

$* \mathrm{p}<0.01 ; * * \mathrm{p}<0.001$.

Based on the data of regression and correlation analysis, it can be generalized that psychological resources are associated with the processes of modification in the self-fulfillment of the individual and at the same time they are their factors, such as creativity and coherence. It is important, that consistency is a factor in each of the three configurations of self-realization.

Correlation analysis was used to determine which psychological resources are related to existential motives and life tasks (Table 10).

The main connections of psychological resources and existential motives and operational analogs of life tasks are illustrated in the table. 9. It is advisable to pay attention to the fact that most of the connections with existential motives and life tasks are held by interpretive resources of creativity and the (c) Shtepa Olena

DOI (article): https://doi.org/10.32626/2227-6246.2021-53.330-354 
DOI: https://doi.org/10.32626/2227-6246.2021-53

2021. випУСК 53

ability to update one's own resources; the least - «strength of character" meaningfulness of life. The ability to update one's resources at a statistically significant level $(p<0.05)$ is not related to life tasks. At the same time, the ability to update one's own resources is related to such existential motives as support $(\mathrm{r}=0.22 ; \mathrm{p}<0.01)$, security $(\mathrm{r}=0.32 ; \mathrm{p}<0.01)$, and fundamental trust $(\mathrm{r}=0.30 ; \mathrm{p}<0.01)$, closeness $(\mathrm{r}=0.28$; $\mathrm{p}<0.01)$, self-worth $(\mathrm{r}=0.30 ; \mathrm{p}<0.01)$, recognition of value $(\mathrm{r}=0.26 ; \mathrm{p}<0.01)$.

Table 10

The results of correlation analysis of psychological resources and existential motives and operational analogs of life tasks

\begin{tabular}{|c|c|c|c|c|c|c|c|c|}
\hline \multirow[b]{2}{*}{$\begin{array}{l}\text { Psychological } \\
\text { resources }\end{array}$} & \multicolumn{5}{|c|}{ Existential motives } & \multicolumn{3}{|c|}{$\begin{array}{c}\text { Operational } \\
\text { analogs of } \\
\text { life tasks }\end{array}$} \\
\hline & 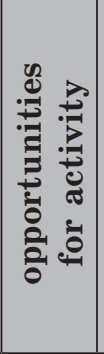 & 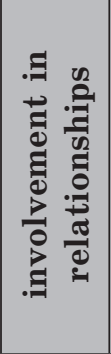 & 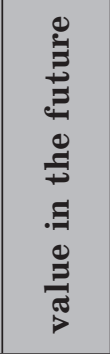 & 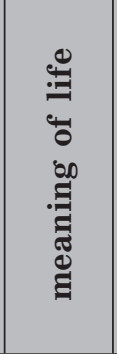 & 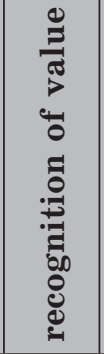 & 密 & 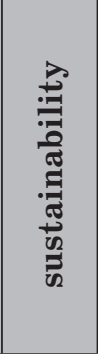 & 承 \\
\hline Creativity & $0.32 *$ & $0.34 * *$ & $0.44 * \%$ & $0.45 * *$ & $0.28 *$ & & $0.24 \%$ & $0.26 *$ \\
\hline Work on yourself & & & $0.36 *$ & $0.26 *$ & & & $0.28 *$ & \\
\hline Coherence & & $0.26 *$ & $0.36 *$ & $0.25 \%$ & & & $0.28 *$ & \\
\hline Mercy & $0.28 *$ & & & & & $0.31 *$ & & \\
\hline $\begin{array}{l}\text { Meaningfulness } \\
\text { of life }\end{array}$ & & $0.32 *$ & & & & & & \\
\hline $\begin{array}{l}\text { Manifestation of } \\
\text { experiences }\end{array}$ & & & $0.35 * *$ & $0.34 * *$ & & & & $0.27 *$ \\
\hline $\begin{array}{l}\text { Ability to update } \\
\text { own resources }\end{array}$ & $0.27 *$ & $0.36 * *$ & $0.44 * \%$ & $0.40 * *$ & $0.32 *$ & & & \\
\hline
\end{tabular}

$$
* \mathrm{p}<0.01 ; * * \mathrm{p}<0.001 \text {. }
$$

(C) Shtepa Olena

DOI (article): https://doi.org/10.32626/2227-6246.2021-53.330-354 
DOI: https://doi.org/10.32626/2227-6246.2021-53

2021. випУСК 53

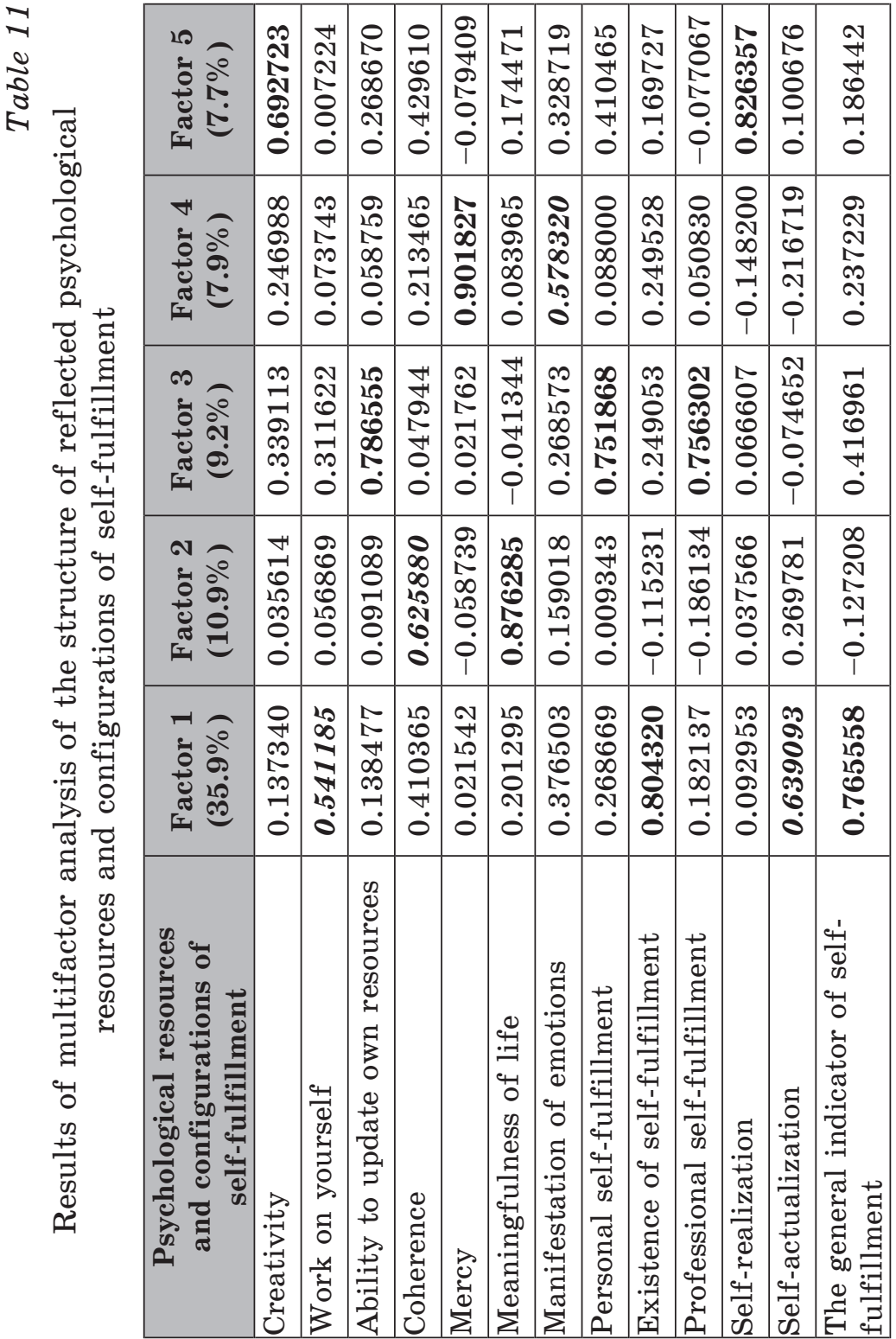

(C) Shtepa Olena

DOI (article): https://doi.org/10.32626/2227-6246.2021-53.330-354 
To characterize the modification in self-fulfillment as a psychological state, a multivariate analysis of reflected psychological resources and configurations of self-fulfillment was used, which cumulatively explained about $72 \%$ of the variance (factor weight $>0.7$ ) (Table 11).

According to the results of multifactor analysis, it is established that in the structure of modification in self-fulfillment it is expedient to state that: a) the resource of work on oneself is one factor with existential self-realization, general indicator of self-fulfillment and self-actualization; b) the ability to update their own resources is one of the factors with personal and professional self-fulfillment; c) the resource of creativity - to one factor with self-fulfillment. Resource coherence in a multifactorial structure is not combined at a statistically significant level $(>0.7)$ with the processes of modification in self-fulfillment.

\section{Conclusions}

According to the results of the study, the reflected psychological resources in the configurations of self-fulfillment existential, personal, and professional self-fulfillment - are the following: creativity, work over oneself, the ability to renew their own resources, coherence, charity, the meaningfulness of life, expression of emotions. It is important that the interpretive resources of "creativity" and «the ability to update one's own resources» are predictors of all three configurations of self-fulfillment; existential resource of "charity» - of existential and personal self-fulfillment, and «strength of character» meaningfulness of life - of personal and professional self-fulfillment.

Psychological resources that moderate the relationship of existential motivation as a manifestation of the inner world of man and life tasks are identified as creativity, self-work, coherence, charity, expression of emotions. In particular, coherence, creativity, and self-improvement are more closely linked

(c) Shtepa Olena

DOI (article): https://doi.org/10.32626/2227-6246.2021-53.330-354 
DOI: https://doi.org/10.32626/2227-6246.2021-53

2021. випуск 53

to the manifestation of the fundamental existential motivation «meaning of life» and the sustainability of life's tasks. The existential resource of charity is related to the motivation of opportunities and the strategic tasks of life. The resource of psychological survival is the «manifestation of emotions» in the triad of connections with the motivation of the meaning of life and the flexibility of life's tasks. The ability to update one's resources is related only to existential motives, which gives grounds to assert that the source of self-change is a truly existential experience of a person.

Psychological resources that are factors of self-realization, self-actualization, self-fulfillment of the individual are creativity, the ability to update their own resources, coherence. At the same time, coherence is a factor for all three configurations of self-fulfillment, creativity is a factor for existential and professional self-fulfillment, and the ability to renew one's own resources is a factor of personal and professional self-fulfillment.

The results of the study give grounds to characterize the following sequence of resource conditioning of changes in self-fulfillment: firstly, due to the resource of self-actualization, the effect of which is existential self-fulfillment as an experience of real and authorial life lived by the individual; further, the ability to update their own resources leads to the transformation of forms in personal and professional self-fulfillment; at the end of the change, the resource of creativity affects the possibility of self-fulfillment of the personality. The whole process of reflected changes is patronized by coherence, as a factor in the significance of a life lived by the person, as well as its optimal and healthy functioning. Therefore, it is important that a person had a systematic reflection to be aware of their own resources, as well as to be able to update their own psychological resources, update the resources of creativity and work on themselves. Since the source of coherence is life experience (Antonovski, 1993), it is important (c) Shtepa Olena

DOI (article): https://doi.org/10.32626/2227-6246.2021-53.330-354 
DOI: https://doi.org/10.32626/2227-6246.2021-53

2021. ВИПУСК 53

to be immersed in living one's own life for self-fulfillment of personality.

\section{Literature}

Гришина Н.В. Экзистенциальный опыт: эмпирические описания. Человек, субъект, личность в современной психологии: Материалы международной конференции, посвященной 80-летию А.В. Брушлинского / отв. ред. А. Журавлев, Е. Сергиенко. Москва : Изд-во «Институт психологии РАН», 2013. С. 283-386.

Гуменюк Г.В. Психологічний простір професійного самоздійснення особистості як предмет дослідження. Проблели загальної та педагогічної психології: Зб. наук. праць Інституту психологї̈ іл. Г.С. Костюка НАПН України, 2014, XVI $(1,2), 299-310$. URL : http://lib.iitta.gov.ua/10079.

Капустин С.А. Вклад У. Джемса в представления о личности как психологической реальности. Национальный психологический журнал, 2017, 1 (25), 62-69.

Кокун О.М. Життєве та професійне самоздійснення як предмет дослідження сучасної психології. Практична психологія та соціальна робота , 2013, 9, 1-5.

Кривцова С., Лэнгле А., Орглер К. Шкала экзистенции (Existenzskala). Экзистенииальный анализ. Бюллетень, 2009, 1, 141-170. Москва. URL : https://laengle.info/userfile/doc/ESK-Krivtsova--L\% C3\% A4ngle-Bull-09.pdf.

Леонтьев Д.А., Миюзова А.Е. Личностные изменения как результат жизнетворческой работы. Консультативная психология и психотерапия, 2016, 24 (1), 44-63. URL : https://doi.org/10.17759/cpp.

Максименко С.Д. Поняття особистості у психології. Психологія і особистість, 2016, 1 (9), 11-17.

Mobilis in mobili: личность в эпоху перемен / под общ. ред. А. Асмолова. Москва : Издательский дом «ЯСК», 2018. 546 с.

Низовских Н.А. Человек как автор самого себя: психосемантическое исследование личностного развития: монография. Москва - Берлин : Директ-Медиа, 2014. 405 с.

Психологічні технології ефективного функціонування та розвитку особистості: монографія / [за ред. С.Д. Максименка, С.Б. Кузікової, В.Л. Зливкова]. Суми : Вид-во СумДПУ імені А.С. Макаренка, 2019. $540 \mathrm{c}$.

Antonovski, A. The structure and properties of the sense of coherence scale. Soc Sci Med., 1993, Mar, 36 (6), 725-733. URL : https://doi. org/10.1016/0277-9536(93)90022-Z.

(C) Shtepa Olena

DOI (article): https://doi.org/10.32626/2227-6246.2021-53.330-354 
DOI: https://doi.org/10.32626/2227-6246.2021-53

2021. випуск 53

Byundyugova, T., \& Kornienko, E. Personality-Related Factors of Self-Fulfillment in Professional Activities. Review of European Studies, 2015, 7 (3). URL : https://doi.org/10.5539/res.v7n3p1.

Clark, S. Narrative, Self-Realization, and the Shape of a Life. Ethical Theory and Moral Practice, 2018, 21 (2), 371-385. URL : https:// doi.org/10.1007/s10677-018-9885-7.

Krems, J., Kenrick, D., \& Neel, R. Individual Perceptions of Self-Actualization: What Functional Motives Are Linked to Fulfilling One's Full Potential? Personality and Social Psychology Bulletin, 2017, 43 (9), 1337-1352. URL : https://doi.org/10.1177/0146167217713191.

Maksimenko, S, \& Serdiuk, L. Psychological potential of personal selfrealization. Social Welfare Interdisciplinary Approach, 2016, 1 (6). URL : http://dx.doi.org/10.21277/sw.v1i6.244.

Shutenko, E. Motivational and Conceptual Aspects of Students' Self-fulfillment in University Educatio. Procedia - Social and Behavioral Sciences, 2015, 214, 325-331. URL : https://doi.org/10.1016/ j.sbspro.2015.11.652.

\section{References}

Grishina, N.V. (2013). Ekzistentsialnyi opyt: empiricheskiie opisaniia [Existential Experience: Empirical Descriptions]. Chelovek, subiekt, lichnost $v$ sovremennoi psikhologii - Man, subject, personality in modern psychology: Proceedings of the international conference dedicated to the 80th anniversary of A.V. Brushlinskii, (pp. 283-386). Moskva : Izd-vo «Institut psikhologii RAN» [in Russian].

Humeniuk, H.V. (2014). Psykholohichnyi prostir profesiinoho samozdiisnennia osobystosti yak predmet doslidzhennia [Psychological space of professional self-realization of the individual as a subject of research]. Problemy zahalnoi ta pedahohichnoi psykholohii: Zb. nauk. prats Instytutu psykholohii im. H.S. Kostiuka NAPN Ukrainy - Problems of general and pedagogical psychology: Collection of research papers of H.S. Kostiuk Institute of Psychology of NAES of Ukraine, XVI (1, 2), 299-310. Kyiv. Retrieved from http://lib.iitta.gov.ua/ 10079 [in Ukrainian].

Kapustin, S.A. (2017). Vklad U. Dzhemsa v predstavleniia o lichnosti kak psikhologicheskoi realnosti [W. James's contribution to the concept of personality as a psychological reality]. Natsionalnyi psikhologicheskii zhurnal - National Psychological Journal, 1 (25), 62-69 [in Russian].

Kokun, O.M. (2013). Zhyttieve ta profesiine samozdiisnennia yak predmet doslidzhennia suchasnoi psykholohii [Life and professional self-ful-

(c) Shtepa Olena

DOI (article): https://doi.org/10.32626/2227-6246.2021-53.330-354 
DOI: https://doi.org/10.32626/2227-6246.2021-53 2021. ВИПУСК 53

fillment as a subject of research of modern psychology]. Praktychna psykholohiia ta sotsialna robota - Practical Psychology and Social Work, 9, 1-5 [in Ukrainian].

Krivtsova, S., Lengle, A., \& Orgler, K. (2009). Shkala ekzistentsii (Existenzskala) [Existence scale (Existenzskala)]. Ekzistentsialnyi analiz - Existence Analysis. Bulletin, 1, 141-170. Moskva [in Russian]. Leontiev, D.A., \& Miiuzova, A.E. (2016). Lichnostnyie izmeneniia kak rezultat zhiznetvorcheskoi raboty [Personal change as a result of life-creating work]. Konsultativnaia psikhologiia i psikhoterapiia Counseling psychology and psychotherapy, 24 (1), 44-63. Retrieved from https://doi.org/10.17759/cpp [in Russian].

Maksymenko, S.D. (2016). Poniattia osobystosti u psykholohii [The concept of personality in psychology]. Psykholohiia i osobystist - Psychology and personality, 1 (9), 11-17 [in Ukrainian].

Asmolov, A. (Ed.) (2018). Mobilis in mobili: lichnost $v$ epokhu peremen [Mobilis in mobili: personality in the era of change]. Moskva : Izdatelskii dom "YaSK» [in Russian].

Nizovskikh, N.A. (2014). Chelovek kak avtor samogo sebia: psikhosemanticheskoie issledovaniie lichnostnogo razvitiia [Man as the author of himself: psychosemantic study of personal development]. Moskva Berlin : Direkt-Media [in Russian].

Maksymenko, S.D., Kuzikova, S.B., \& Zlyvkov, V.L. (Eds.) (2019). Psykholohichni tekhnolohii efektyvnoho funktsionuvannia ta rozvytku osobystosti [Psychological technologies of effective functioning and development of personality]. Sumy : Vyd-vo SumDPU imeni A.S. Makarenka [in Ukrainian].

Antonovski, A. (1993). The structure and properties of the sense of coherence scale. Soc Sci Med., 36 (6), Mar, 725-733. Retrieved from https://doi.org/10.1016/0277-9536(93)90022-Z.

Byundyugova, T., \& Kornienko, E. (2015). Personality-Related Factors of Self-Fulfillment in Professional Activities. Review of European Studies, 7 (3). Retrieved from https://doi.org/10.5539/res.v7n3p1.

Clark, S. (2018). Narrative, Self-Realization, and the Shape of a Life. Ethical Theory and Moral Practice, 21 (2), 371-385. Retrieved from https://doi.org/10.1007/s10677-018-9885-7.

Krems, J., Kenrick, D., \& Neel, R. (2017). Individual Perceptions of Self-Actualization: What Functional Motives Are Linked to Fulfilling One's Full Potential? Personality and Social Psychology Bulletin, 43 (9), 1337-1352. Retrieved from https://doi.org/10.1177/ 0146167217713191.

(C) Shtepa Olena

DOI (article): https://doi.org/10.32626/2227-6246.2021-53.330-354 
Maksimenko, S., \& Serdiuk, L. (2016). Psychological potential of personal self-realization. Social Welfare Interdisciplinary Approach, 1 (6). Retrieved from http://dx.doi.org/10.21277/sw.v1i6.244.

Shutenko, E. (2015). Motivational and Conceptual Aspects of Students' Self-fulfillment in University Education. Procedia - Social and Behavioral Sciences, 214, 325-331. Retrieved from https://doi.org/ 10.1016/j.sbspro.2015.11.652.

\section{Штепа Олена. Психологічні ресурси перетворень у самоздійсненні осо- бucmocmi}

\section{АНОТАЦІЯ}

Мета дослідження - емпіричне визначення психологічних ресурсів перетворень у самоздійсненні особистості.

В емпіричному дослідженні використано методи психологічного опитування, а також такі методи математико-статистичного аналізу даних, як: регресійний, кореляційний, класифікаційний, дискримінантний, багатофакторний аналіз. Емпіричне дослідження реалізовано за моделлю Нельсона, що уможливливило характеристику шуканих психологічних ресурсів за допомогою їх дискримінування.

Результати дослідження. З'ясовано, що рефлексованими психологічними ресурсами у конфігураціях самоздійснення особистості - екзистенційному, особистісному і професійному самоздійсненні - $\epsilon$ такі: творчість, робота над собою, уміння оновлювати власні ресурси, когерентність, милосердя, осмисленість життя, вияв емоцій. Інтерпретативні ресурси «творчість» $i$ «уміння оновлювати власні ресурси» $\epsilon$ предикторами усіх трьох конфрігурацій самоздійснення. Психологічними ресурсами, що модерують співвідношення екзистенційної мотивації як вияву внутрішнього світу людини і життєвих завдань, виокремлено такі, як творчість, робота над собою, когерентність, милосердя, вияв емочій. Психологічними ресурсами, що є чинниками самоздійснення, самоактуалізації, самореалізації особистості, є творчість, уміння оновлювати власні ресурси, когерентність. Когерентність є чинником для усіх трьох конфігурацій самоздійснення.

Висновки. Послідовність ресурсної зумовленості перемін у самоздійсненні є такою: спочатку завдяки ресурсу роботи над собою відбувається самоактуалізація, ефектом чого постає екзистенційне самоздійснення як переживання справжнього й авторського життя, що його проживає (c) Shtepa Olena

DOI (article): https://doi.org/10.32626/2227-6246.2021-53.330-354 
DOI: https://doi.org/10.32626/2227-6246.2021-53

2021. ВИПУСК 53

особистість; далі уміння оновлювати власні ресурси зумовлює переінакшення форм в особистому і профресійному самоздійсненні; на завершення переміни ресурс творчості впливає на уможливлення самореалізації особистості. Увесь прочес рефлексованих перемін патронується когерентністю як чинником значущості життя, що його проживає особистість, а також ії оптимального і здорового функціонування.

Ключові слова: психологічні ресурси, самоактуалізація, самореалізація, самоздійснення, особистісні переміни.

\section{Штепа Елена. Психологические ресурсы преобразований в самоосуще- ствлении личности}

\section{АННОТАЦИЯ}

Цель исследования - эмпирическое определение психологических ресурсов преобразований в самоосуществлении личности.

В эмпирическом исследовании использованы методы психологического опроса, а также такие методы математико-статистического анализа данных, как: регрессионный, корреляционный, классификационный, дискриминантный, многофакторный анализ. Эмпирическое исследование реализовано по модели Нельсона, что сделало возможным характеристику искомых психологических ресурсов с помощью их дискриминирования.

Результаты исследования. Установлено, что отрефлексированными психологическими ресурсами в конфригурациях самоосуществления личности - экзистенциальном, личностном, профессиональном - являются такие: творчество, работа над собой, умение обновлять собственные ресурсы, милосердие, осмысленность жизни, проявление эмоций. Интерпретативные ресурсы "творчество» и "умение обновлять собственные ресурсы» являются предикторами всех трех конфигураций самоосуществления. Психологическими ресурсами, модерирующими соотношение экзистенциальной мотивации как проявления внутреннего мира человека и жизненных заданий, выделено такие, как творчество, работа над собой, когерентность, милосердие, проявление эмоций. Психологическими ресурсами, влияющими на самоосуществление, самоактуализацию, самореализацию, являются творчество, умение обновлять собственные ресурсы, когерентность. Когерентность обуславливает все три конфигурации самоосуществления.

(C) Shtepa Olena

DOI (article): https://doi.org/10.32626/2227-6246.2021-53.330-354 
DOI: https://doi.org/10.32626/2227-6246.2021-53

2021. випУСК 53

Выводы. Последовательность ресурсной обусловленности преобразований в самоосуществлении является такой: сначала благодаря ресурсу работы над собой происходит самоактуализация, эфрфектом чего становится экзистенциальное самоосуществление как переживание личностью своей жизни, как настоящей и авторской; далее умение обновлять собственные ресурсы обуславливает модирикации форм в личностном и профессиональном самоосуществлении; в завершение изменений ресурс творчества влияет на совершение самореализации личности. Весь процесс отрефрлексированных изменений патронируется когерентностью как фрактором значимости жизни, проживаемой личностью, а также ее оптимального и здорового функционирования.

Ключевые слова: психологические ресурсы, самоактуализация, самореализация, самоосуществление, личностные преобразования.

Original manuscript received April 25, 2021 Revised manuscript accepted May 29, 2021 